\title{
Effects of the Combination of Rice By-Products (Fermented Straw and Bran) and Legumes (Leucaena and Gliricidia Leaves) on the Growth Rate of Male Bali Cattle
}

\author{
Carlito de Araújo Mali Code ${ }^{1}$, Graciano Soares Gomes ${ }^{1, ~ *, ~}$ \\ Alberto Agostinho Pereira da Costa Joao ${ }^{2}$ \\ ${ }^{1}$ Department of Animal Science, Faculty of Agriculture, National University of Timor Lorosa'e, Dili, East Timor \\ ${ }^{2}$ Department of Animal Health, Faculty of Agriculture, National University of Timor Lorosa'e, Dili, East Timor
}

\section{Email address:}

graciano_gomes@yahoo.com (G. S. Gomes)

${ }^{*}$ Corresponding author

\section{To cite this article:}

Carlito de Araújo Mali Code, Graciano Soares Gomes, Alberto Agostinho Pereira da Costa Joao. Effects of the Combination of Rice ByProducts (Fermented Straw and Bran) and Legumes (Leucaena and Gliricidia Leaves) on the Growth Rate of Male Bali Cattle. International Journal of Animal Science and Technology. Vol. 5, No. 2, 2021, pp. 38-41. doi: 10.11648/j.ijast.20210502.12

Received: April 25, 2021; Accepted: May 20, 2021; Published: May 27, 2021

\begin{abstract}
To increase the quality of dry rice straw and meet the needs of nutritional requirement for livestock, availability and technology should be considered to come up with an improve that is easy and inexpensive feeding material. The research aims to find out the effects of the combination of rice by-products (dry fermented straw and bran) with legumes (Leucaena and Gliricidia leaves) in increasing the growth of Bali cattle. This research was conducted at the Maliana Administrative, Bobonaro Municipality, from August 28, 2019 to November 17, 2019. In this research, five (5) male and growing beef cattle were used. This research method used the experimental method with Latin Square Design consisting of five treatments and five replications. The feed combinations or treatments used for beef cattle ration formulations, were: T1 is composed of $40 \%$ fermented rice straw, $20 \%$ rice bran, $10 \%$ Gliricidia and 30\% Leucaena; T2 is composed of $55 \%$ fermented rice straw, $10 \%$ rice bran, $20 \%$ Gliricyda and $15 \%$ leucaena; T3 is composed of 50\% fermented rice straw, $5 \%$ rice bran; $35 \%$ Gliricyda, and $15 \%$ leucaena; T4 is composed of $45 \%$ fermented rice straw, $15 \%$ rice, $30 \%$ Gliricyda, and $10 \%$ leucaena; T5 is composed of $30 \%$ fermented rice straw, $25 \%$ rice, $5 \%$ Gliricyda, and $40 \%$ leucaena. The variables observed were feed intake $(\mathrm{kg})$, feed conversion and animal body weight $(\mathrm{kg})$. Data analysis show that no significant effect $(\mathrm{P}>0.05)$ on ration consumption but had a significant effect $(\mathrm{P}<0.05)$ on body weight gain and feed conversion of all experimental beef cattle used in the study. The result of comparison of mean show that the treatment $\mathrm{T} 3$ can accelerate growth and improve feed conversion of male beef cattle in their growth phase.
\end{abstract}

Keywords: Beef Cattle, Rice Straw, Fermentation, Leguminous Leaves

\section{Introduction}

Beef cattle is a ruminant livestock that has great potential to produce high quality meat to meet human consumption needs, especially for the protein. Beef cattle in Timor-Leste (TL) has become a familiar type of livestock in various parts of the territory and is maintained through traditional extensive system. In 2015, a total of 52,864 households (25.84\%) registered 221,767 beef cattle. Each household keeps four to five heads of cattle as their secondary farming activity. Majority of cattle owners focus on agricultural activities such as rice cultivation and backyard gardening. In other parts of the country, there is a need to develop the potential of beef cattle starting from the improvement of local feed utilization. Availability and potential of indigenous feed resources can help manage the need for livestock feeds. In livestock production, three important factors have to be considered namely, quantity and quality of feeds, and management. Among these production activities, quality and quantity of feeds are very critical due to the huge expenditure 
incurred to acquire feed with good and high nutritional composition for growth and meet consumer/market demand.

Rice straw is one of the by-products of rice production at harvest. Rice straw is removed with the rice grains during harvest and ends up being piled or spread out in the field and just burned which could have a negative impact on the environment. It is a readily available, practical, and cheap source of fodder for feeding ruminants such as buffaloes, cattle, goats, and sheep. Livestock producers commonly haul and stack rice straw from their rice farm, which then forms reserved feed for their animals during lean months or when good-quality roughages are scarce. The feeding of pure rice straw to ruminants during the stages of fast growth and early lactation has been shown to affect both body condition score and animal performance. This is due to lower dry matter intake and protein content (from $4.0 \%$ to $4.7 \%$ crude protein) of the straw. The high silica and lignin contents of straw also contribute to poor nutrient (dry matter and protein) digestibility $<50 \%$ [3]. Fermentation of rice straw can improve quality especially crude protein and energy and make feed components easier to digest [15]. Rice bran, another by-product of rice, has moderate energy content and moderate to moderately-high protein content. This feedstuff makes a good forage substitute when forage supply is limited.

To increase the quality of dry rice straw and meet the needs of nutritional requirement for livestock, availability and technology should be considered to come up with an improve that is easy and inexpensive feeding material. Technology-based farm strategies to optimize the nutritive and feeding value of rice straw can be done by the incorporation of leguminous tree species such as Leucaena leucocephala (Lam.) and Gliricidia sepium (Jacq.) to become high quality animal feed [12-14]. Leucaena leucocephala leaves contains $22.09 \%$ crude protein which can promote and accelerate growth of livestock. G. sepium is rich in protein $(23 \% \mathrm{CP})$ and calcium $(1.2 \%)$. It has high fiber content $(45 \%$ NDF) which makes it a good roughage source for ruminants [6]. Gliricidia is a fresh feed that can be given to cows because it has a high nutritional content, especially crude protein around $23.5 \%$ [2].

Ruminants require feeds composed of $60-75 \%$ carbohydrates, $12 \%$ crude protein, 3-5\% lipids and other substances such as vitamins and minerals. Level of consumption of ruminants is based on dry matter in the form of fresh feed and concentrate feed. DM consumption of ruminants such as cattle is $3-4 \%$ of the body weight of the livestock itself [1].

Based on the above premises the researchers are encouraged to utilize local feed materials such as fermented dry rice straw, rice bran and leaves Gliricidia and Leucaena in the formulation of four combinations of ration. Intensive observations were done during the duration of the study period. The research aims to find out the effects of the combination of rice by-products (dry fermented straw and bran) with legumes (Leucena and Gliricidia leaves) in increasing the growth of Bali cattle.

\section{Methods}

Description of the study area: This research was conducted at the Maliana Administrative, Bobonaro Municipality west East Timor, from August 28, 2019 to November 17, 2019.

\subsection{Animals and Experimental Design}

In this research, five (5) male and growing beef cattle were used. All beef cattle are purchased from farmers residing near the research area. These animals were kept using an extensive system. The beef cattle were kept in a cage-type barn with a total area of $12 \times 5 \mathrm{~m}$ and divided into 10 slots/compartments with permanent eating and drinking troughs. Only five 5 compartments were used for the experiment. This research method used the experimental method with Latin Square Design (5x5), consisting of five treatments and five replications.

\subsection{Type of Local Food Used and Feed Formulation}

Local feed sources used in feed formulation are composed of dry fermented rice straw, rice bran and leaves of Leucaena Leucocephala and Gliricidia. In the production of probiotics, for dry rice straw fermentation the following proportions were used: 2 ripe pineapples, 2 coconuts (just use the water), $250 \mathrm{~g}$ sugar, $300 \mathrm{~g}$ palm sugar, $300 \mathrm{ml}$ EM-4, 5 liters of water and one bucket. In the blender, put it in a bucket, cover it tightly, (anaerobic) and put it in a safe place for 21 days after which it is mixed with clean water (1 liter of probiotic: 50 liters of clean water) to make fermentation of dry rice straw $300-350 \mathrm{~kg}$. Fermentation lasted for 21 days for safe and anaerobic process. The feed combinations (treatments) used for beef cattle ration formulations, were: $\mathrm{T} 1$ is composed of $40 \%$ fermented rice straw (FRS), 20\% rice bran (RB), 10\% Gliricidia (GL) and 30\% Leucaena (LL); T2 is composed of $55 \%$ FRS, $10 \% \mathrm{RB}, 20 \% \mathrm{GL}$ and $15 \% \mathrm{LL} ; \mathrm{T} 3$ is composed of $50 \% \mathrm{FRS}, 5 \% \mathrm{RB} ; 35 \% \mathrm{GL}$, and $15 \% \mathrm{LL}$; $\mathrm{T} 4$ is composed of $45 \% \mathrm{FRS}, 15 \% \mathrm{RB}, 30 \% \mathrm{GL}$, and $10 \%$ LL; T5 is composed of $30 \% \mathrm{FRS}, 25 \% \mathrm{RB}, 5 \% \mathrm{GL}$, and $40 \%$ LL. Variables observed: feed intake $(\mathrm{kg})$, feed conversion ratio and animal body weight $(\mathrm{kg})$.

\subsection{Statistical Analysis}

Data collected were subjected to analysis of variance (ANOVA) at $\mathrm{P}<0.05$ level of significance, using the General Linear Model (GML) procedure of SPSS version 25 (Santoso, 2018). Mean comparisons were made by using Duncan test method at $\mathrm{P}<0,05$. The Statistical model $Y i j k=\mu+E i+E i j k$. Where: $Y i j k=a n$ observation for given variables, $\mu=$ over all mean, $E i=$ effect of the $i^{\text {th }}$ treatment (i: 1 , 2, 3, 4, 5), Eijk=residual random error.

\section{Results and Discussions}

\subsection{Results}

The results of the analysis of variance (ANOVA) on the 
three variables to measure growth of Bali beef cattle is shown in Table 1 and Figure 1. The result of mean comparisons revealed that the $\mathrm{T} 3$ is the best treatment to feed beef cattle, especially in terms of body weight gain and feed conversion rate. However, the treatments showed no different effects on feed consumption.

Table 1. The results of the research on the growth phase of male cattle fattening in Maliana.

\begin{tabular}{llllll}
\hline \multirow{2}{*}{ Observation } & Treatment & & & & \\
\cline { 2 - 5 } & T1 & T2 $^{2}$ & T3 & T4 & T5 \\
\hline CR. 1 (kg DM) & $14.97 \mathrm{a} 3$ & $15.04 \mathrm{a}$ & $15.43 \mathrm{a}$ & $15.46 \mathrm{a}$ & $15.95 \mathrm{a}$ \\
BWG $(\mathrm{kg} / \mathrm{P})$ & $10.40 \mathrm{~b}$ & $9.18 \mathrm{~b}$ & $12.33 \mathrm{a}$ & $8.92 \mathrm{~b}$ & $9.24 \mathrm{~b}$ \\
FCR & $15.55 \mathrm{~b}$ & $20.18 \mathrm{~b}$ & $17.04 \mathrm{a}$ & $21.64 \mathrm{~b}$ & $9.75 \pm 1.71$ \\
\hline
\end{tabular}

Observations:

1. CR: Consumption Ration; BWG: Body Weight Gain; FCR: Feed Conversion Ration.

2. Treatments: T1 is composed of $40 \%$ fermented rice straw (FRS), $20 \%$ rice bran (RB), $10 \%$ Gliricidia (GL) and $30 \%$ Leucaena (LL); T2 is composed of $55 \% \mathrm{FRS}, 10 \% \mathrm{RB}, 20 \%$ GL and $15 \% \mathrm{LL}$; T3 is composed of 50\% FRS, $5 \%$ RB; $35 \%$ GL, and $15 \%$ LL; T4 is composed of $45 \% \mathrm{FRS}, 15 \% \mathrm{RB}, 30 \% \mathrm{GL}$, and $10 \% \mathrm{LL}$; T5 is composed of 30\% FRS, 25\% RB, 5\% GL, and 40\% LL. Columns with different letters are significant at 5\% level.

3. SEM: Standard Error Mean.

The results of the comparison test showed that there was no significant effect $(\mathrm{P}>0.05)$ on ration consumption but had a significant effect $(\mathrm{P}<0.05)$ on body weight gain and feed conversion ratio of all experimental beef cattle used in the study. The treatment effect on body weight gain and feed conversion was observed in $\mathrm{T} 3$ indicative that it is better than all other treatments.

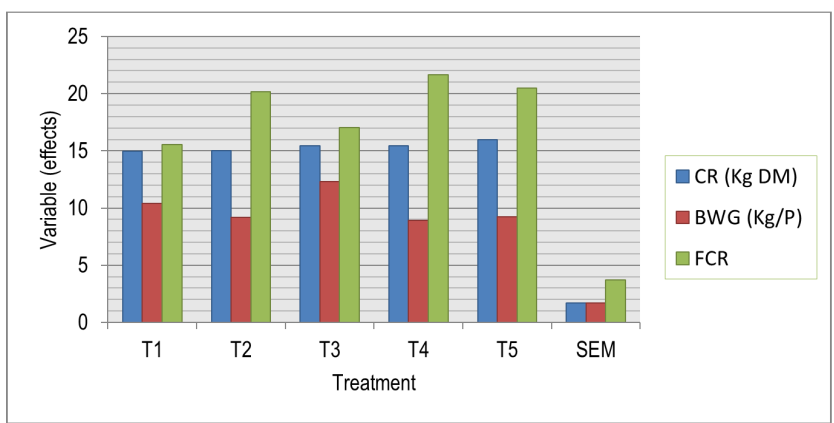

Figure 1. The effects of the different treatments on the growth of beef cattle.

Observations: CR: Consumption Ration; DM: Dry matter; BWG: Body Weight Gain.

(kg/period); FCR: Feed Conversion Ration.

\subsection{Discussions}

\subsubsection{Consumption of Ration}

The results of statistical analysis that consumption of ration of 5 male beef cattle used in the research showed no significant effect $(\mathrm{P}>0.05)$. These results indicate that the ration formulation consisting of fermented rice straw, rice bran, L. leucaena, and G. sepium leaves did not affect feed intake of each livestock to be able to support the needs for life maintenance and production. This can be attributed to the physical composition and nutritional content of ration which is not very different, especially crude protein (CP) which provides the main function to control consumption and accelerate the growth of livestock. Sutrisno [13] reported that there are many factors that influence the consumption of ration including the physical preparation of the feed, color, temperature of the environment especially in the cage, availability of clean water and physiological status of the animal. In a similar vein, level of feed consumption of ruminants is influenced by the deliciousness of the ration, digestibility, sex, and physiological status [4]. Internal factors of livestock might have affected ration consumption such as $\mathrm{pH}$ of stomach secretions, especially rumen, which can affect the fermentation of feed used for ration formulations [7]. The provision of animal feed needs to pay attention to the quality of the nutrients needed by the body of the livestock [11].

\subsubsection{Feed Conversion Ration}

The results of statistical analysis on feed conversion ratio showed that feed formulation had significant effect $(\mathrm{P}<0.05)$. This means that although there is no difference in ration consumption, experimental beef cattle were able to efficiently digest feed offered enabling them to gain weight. The Duncan's test showed that beef cattle receiving T3 had better feed conversion which translates to a requirement of $17.40 \mathrm{~kg}$ feed to produce $1 \mathrm{~kg}$ body weight. On the other hand, cattle receiving T1, T2, T4 and T5 need 17.55-21.64 feed to convert at $1 \mathrm{~kg}$ body weight. Soewardi [10] articulated that feed conversion capacity depends more on the quality of the feed itself, especially the quality of the protein. In particular, T5 had higher nutrient composition (14.51\%) compared to other treatments (T1, T2, T3 and T4) with $11.87 \%, 12.74 \%, 13.19 \%$ and $12.88 \%$ protein, respectively. However, results show that beef cattle under T3 performed better than those in other treatments. This means that it is the protein content of the feed which contributed to efficiency of converting feed to the growth of beef cattle.

\subsubsection{Body Weight Gain}

The results of statistical analysis on body weight gain showed that there was significant effect $(\mathrm{P}<0.05)$ in each period. The Duncan's test showed that beef cattle receiving T3 had higher body weight gain compared with those under T1, T2, T4 and T5. Beef cattle under T3 within a period of 14 days was able to increase weight of $10.86 \mathrm{~kg}$ or $0.776 \mathrm{~kg}$ in a day compared with those receiving other treatments (Table 1). These results indicate that the nutritional composition of T3 has been able to respond to the needs of living maintenance and beef cattle production, although there is no difference in ration consumption but there is a significant 
difference in feed conversion. Therefore, feed efficiency depends on the proper utilization of feed in beef cattle. This finding is supported by Mcllroy [5] who reported that an adequate, balance and good quality feed is determinant factor for increasing livestock production. Sonjaya [9] reported that growth is a change in the linear size of the body and all body components such as bones, tendons, and fat which in turn can affect the live weight of the livestock.

\section{Conclusion}

Based on the results of this study, it can be said that the local feed used in formulating the ration in this study is of good quality. The combination of $40 \%$ fermented rice straw, $20 \%$ rice bran, $10 \%$ G. sepium and $30 \%$ L. leucocephala leaves can accelerate growth and improve feed conversion of male beef cattle in their growth phase.

\section{Author's Contributions}

Carlito de Araujo Mali Code: Selected the research topics, shared, editing and revising de manuscript. Graciano Soares Gomes: Planed and design the research methodology, design of dry straw fermentation method, data analysis and shared in drafting of the manuscript. Alberto Agostinho Pereira da Costa Joao: Feed formulation, data colection and animal health care.

\section{Conflicts of Interest}

The authors declare that no conflicts of interest regarding the publication of this article.

\section{Acknowledgements}

This research was supported by the Center of National Scientific Investigation (CNIC) of the National University Timor Lorosa'e (UNTL).

\section{References}

[1] Abidin, Z. (2002). Beef Cattle Fattening. PT Agromedia Pustaka Bintaro Jaya Sector IX J1. Razawali IV Block HDX No. 3 Tangeran. Indonesia. (In Indonesia)

[2] Adiwimarta, K. I. S. (2012). Measuring the Quality of Feed for Cattle. Citra Aji Parama, Yogyakarta. Indonesia.
[3] Aquino, D., Del Barrio, A., Xuan Trach, N., Thanh Hai, N., Nguyen Khang, D., Tat Toan, N. and Van Hung, N. (2020). Chapter 7. Rice Straw-Based Fodder for Ruminants in M. Gummert et al. (eds.), Sustainable Rice Straw Management, https://doi.org/10.1007/978-3-030-32373-8-7.

[4] Church, D. C. (1999). Factors Affecting Feed Consumption In: D. C. Church. Livestock Feed and Feeding. Durham and Dawney. Inc. pp. 136-139.

[5] Mcllroy, R. J. (1977). Introduction to Tropical Grassland Cultivation. Prandya Paramita Jakarta.

[6] Rusdy, M., Baba, S., Garantjang, S., and Syarif, I. (2019). Effects of supplementation with Gliricidia sepium leaves on performance of Bali cattle fed elephant grass. Livestock Research for Rural Development. Volume 31. Article \#84. Retrieved March 30, 2021, from http://www.lrrd.org/lrrd31/6/muhru31084.html.

[7] Sarwono, B. Dan and Hario, B. A. (2001). Beef Cattle Fattening Quickly. P. T. Penebar, Swadaya. Jakarta.

[8] Santoso, S. (2018). Mastering Statistics with SPSS Version 25. Case Study. All in One. A practical and fast way to master statistics in the era of information technology. Publisher PT Media Komputindo. Kompas Gramedia. Jakarta, Indonesia (In Indonesia).

[9] Sonjaya (2012). Basic Animal Physiology. Bogor Agricultural Institute (IPB), Bogor, Indonesia.

[10] Soewardi, B. (1974). Nutrition of Ruminants. Faculty of Animal Husbandry, Institute of Agriculture Bogor. Bogor. (In Indonesia).

[11] Sugeng, Y. B. (2005) Beef Cattle. Publisher: Penebar Swadaya Jakarta, Indonesia.

[12] Sunarso, (2003). Feed Integration in the System Integration of Livestock- Agriculture (Inauguration Speech for University. Professors Diponeg-goro 10 September 2003). The University Diponeggoro Semarang Publisher. Semarang. (In Indonesia).

[13] Sutrisno, C, I. (2001). Integration of Engineering Technology and its Implementation. Journal of Tropical Livestock Development. Special Edition: KS 1-9.

[14] Utomo, R. (2004). Review of the Results of Research on Beef Cattle Feed. Wartozoa, 14 (3): 116-124.

[15] Zakaria, Y. Novita, C. I. \& Samadi, S. (2013). Effectiveness of Fermentation with Different Substrate Sources on the Quality of Rice Straw. Journal of Agrpet, 13 (1) 22. https://doi.org./10.17969/Agripet.V13.i1.548. 